\title{
Strategi Pengembangan Agribisnis Peternakan Ayam Ras Petelur Di Kabupaten Kediri
}

\author{
Agung Dwi Cahyo \\ Program Studi Magister Agribisnis Program Pascasarjana \\ Universitas Islam Kadiri \\ Jl. Sersan Suharmaji No. 38 Kota Kediri Jawa Timur Telp./Fax. (0354) 683243
}

\begin{abstract}
This research is conducted to determined the suitable strategy towed agribusiness development of layer chicken livestock, by understanding the business owner profile to analyse SWOT (strenght, weakness, opportunity, threat) factor. Agribusiness perform important role, it includes production circle, yield processing, and product selling. Strategy analysis is cundected in external and internal environment. Beside that, the demand of highnutrient chicken egg keep increasing annually. Through this strategy to exploit and to create a new opportunity must be supported by missions, purpose, and the environment codition, and it is expected to mee the demand of chicken population increase among business owner especially in kediri ration.

The research was using descriptive method by collecting variabels of the size ofeach individu, interview equipment, and questions list in quisioner,sampling method was random sampling to 15 person business owner in three different villages in regency kediri. The criteria of the interviewee was business owner with around 500 to 10.000 chicken populations.

Layer chicken business is a promising business because a chicken can produce averagely 250 to 280 egg per year, the chicken must be maintained based on environment standard including cage sanitation and quality of the food. There are 3 stage of growing layer chicken, thy are starter stage, grower stage and layer stage. The biggest output in chicken livestock is the feed. Therefore, self produced feed is the one becomes the most suggested by mixing the cornmill and consentrate to minimalize the cost. Based on the date from central bureau of statistic, the demand of chicken eggs are still realtively high, because egg has been known as one of food material that contain good nutrition. Thanks to the cooperation relation between business owner, middle man, and village local cooperation which can increase the income of local business owner. Ngancar with it's strategic location provide practical egg distribution to the middle man or the cansument. Therefore, SWOT, EFAS, IFAS analysis application are suitable to the chicken business development, either for present condition or the future, also considering the price fluctuation can be considered as a threat to the business owner, hopefully this research may give solution to change the threat into the new opportunity to increase the quality of layer chicken livestock around kediri regency
\end{abstract}

Keyword: evironment factor, layer chicken owner, agribusiness development strategy

\section{Abstrak}

Penelitian ini bertujuan untuk menentukan strategi yang tepat terhadap pengembangan agribisnis peternakan ayam ras petelur dengan mengetahui profil peternak secara langsung serta melakukan analisa terhadap faktor Strength (kekuatan), Weakness (kelemahan), opportunity (Kesempatan), dan threat (ancaman). Agribisnis dinilai sangat penting, karena di dalamnya mencangkup rantai produksi, pengolahan hasil, dan pemasaran produk peternakan. Analisa strategi dilakukan terhadap lingkungan eksternal dan internal yang sering kali mengalami perubahan. Disamping itu, tingkat kebutuhan masyakat terhadap telur ayam yang memiliki kandungan gizi tinggi menunjukkan peningkatan dari tahun ke 
tahun. Melalui strategi yang digunakan untuk mengekploitasi dan menciptakan peluang baru tentunya disertai dengan misi, tujuan, dan kondisi lingkungan eksternal dan internal yang mendukung diharapkan mampu untuk meningkatkan populasi peternak ayam ras petelur terutama di wilayah Kabupaten Kediri.

Penelitian ini termasuk dalam penelitian deskriptif dengan metode survei melalui pengumpulan sejumlah variabel mengenai jumlah besar individu, penggunaan alat ukur wawancara, dan beberapa daftar pertanyaan yang berbentuk kuisioner. Metode pengambilan sample dilakukan dengan random sampling terhadap 15 orang peternak secara acak dari tiga desa di kecamatan Ngancar Kabupaten Kediri. Kriteria peternak terpilih adalah peternak dengan kepemilikan populasi ayam ras petelur antara $500-10.000$ ekor.

Usaha peternakan ayam ras petelur sangat menjajikan karenakemampuan produksi ayam yang cukup tinggi antar $250-280$ butir telur/tahun.Managemen pemeliharaan yang dilakukan minimal harus sesuai standart taraf hidup ayam ras petelur termasuk kondisi lingkungan, kebersihan kandang, pakan yang berkualitas, dan pemelihaarn yang baik. Proses pemelihaan ayam ras petelur terdiri dari tiga fase, yaitu fase starter (persiapan kandang), fase grower (pemberian pakan yang tepat), dan fase layer (pemindahan ayam ke kandang baterai untuk reproduksi). Output terbesar dalam managemen pemeliharaan ayam ras petelur adalah pakan. Oleh karena itu, pembuatan pakan sendiri sangat dianjurkan salah satunya dengan campuran jagung katul dan kosentrat sehingga mampu menekan biaya pengeluaran. Berdasarkan data yang diperoleh melalui Badan Pusat Statistik, kebutuhan pasar terhadap telur ayam ras masih cukup tinggi, karena telur telah banyak dikenal oleh masyarakat sebagai bahan masak maupun olahan lainnya. Dengan hubungan kerjasama yang telah dijalin oleh peternak dengan para pengepul dan beberapa badan kredit desa telah mampu meningkatkan hasil pendapatan para peternak ayam ras petelur. Lokasi desa Ngancar yang strategis akan memberikan kemudahan dalam proses pendistribusian telur kepada para pengepul maupun konsumen. Oleh karena itu, penerapan stategi seperti analisa SWOT, analisa EFAS dan IFAS yang sesuai dengan perkembangan lingkungan peternakan baik yang saat ini terjadi maupun yang akan datang termasuk salah satunya adalah fluktuasi harga yang menjadi ancaman tersendiri bagi para peternak, diharapkan mampu memberikan solusi dan mampu merubah suatu ancaman menjadi peluang baru untuk meningkatkan usaha ayam ras petelur khusunya di wilayah Kabupaten Kediri.

Kata kunci : Faktor lingkungan, Peternak ayam ras petelur, dan strategi pengembangan angribisnis

\section{PENDAHULUAN}

Agribisnis memiliki peran yang penting karena sector kegiatan yang mencangkup rantai produksi, pengolahan hasil, dan pemasaran terutama pada peternakan ayam ras petelur (Fajar, 2013).Berdasarkan data Badan Pusat Statistik (BPS) menyatakan bahwa konsumen telur di Indonesia menunjukkan peningkatan dari tahun ketahun dengan rata-rata konsumsi perkapital telur ayam ras tahun 2017 sekitar $2,119 \mathrm{Kg}$. Telur merupakan salah satu bahan protein hewani dengan nilai gizi yang tinggi. Peningkatan jumlah konsumsi telur berbanding lurus dengan peningkatan usaha peternakan ayam ras petelur khususnya di wilayah Kabupaten Kediri.
Penelitian inidilakukan untuk mengetahui perencanaan strategi bisnis yang tepat untuk mengembangkan usahaserta mampu bertahan dalam persaingan yang semakin ketat dan menghadapi lingkungan yang selalu berubah. Untuk merumuskan strategi yang efektif, maka diperlukan serangkaian proses analisis internal dan eksternal guna mengidentifikasi faktor kunci yang terkait dengan pengembangan usaha peternakan ayam ras petelur.Alat analisis yang dapat digunakan dalam pengembangan usaha peternakan ayam ras petelur adalah analisis Strength-Weakness-OpportunityThreath (SWOT) dan analisis Quantitative Strategic Planning Matrix (QSPM) yang digunakan untuk menentukan strategi bisnis terbaik bagi perusahaan 
berdasarkan analisis faktor internal dan eksternal.

\section{METODE PENELITIAN}

Penelitian ini dilaksanakan di Kabupaten Kediri yang terletak pada dataran rendah dengan ketinggian \pm 4.000 mdpl dengan suhu 21-23 ${ }^{\circ} \mathrm{C}$ dan luas wilayah $94,05 \mathrm{~km}^{2}$ yang terdiri dari sepuluh desa (BPS Kabupatenkediri, 2017). Penelitian ini bersifat deskriptif dengan metode survey. Metode pengambilan sample secara random terhadap 15 peternak ayam ras petelur pada tiga desa tempat penelitian yang memiliki populasi ayam ras petelur sebanyak 500 - 10.000 ekor.

Parameter yang diamatiantaralain :

1. Analisa SWOT

Menganalisis permasalahan dengan pengkajian tentang suatu konsep startegi dengan menentukan factor kekuatan (strengths), kelemahan (weaknsses), peluang (opportunities) dan faktoran caman (threats) sehingga faktor-faktor tersebut dapat diidentifkasi berdasakan stategi internal dan stategi eksternal. AnalisaSWOT dilakukan dengan tahapan sebagai berikut :

1. Tahapanmatrik SWOT

2. Tahapanmatrik IFAS dan EFAS

3. Tahapan Analisis Penentuan Strategi

HASIL

Kabupaten kediri yang strategis menjadikannya lokasi yang cocok untuk pengembangan ayam ras petelur. Dari data variabel yang dikumpulkan berdasarkan wawancara dan pengajuan pertanyaan berupa kuisioner maka diperoleh sebuah data yang kemudian dianalisa untuk menentukan stategis yang tepat terhadap perkembangan peternakan ayam ras petelur dengan analisa SWOT.

Tabel 1.Penentuan internal strategic factor analysis summary (IFAS) Terhadap peternak ayam ras petelur.

\begin{tabular}{|c|c|c|c|c|}
\hline NO & FaktorStrategi Internal & \multirow[t]{2}{*}{ BOBOT } & \multirow[t]{2}{*}{ RATING } & \multirow[t]{2}{*}{ SKOR } \\
\hline 1 & kekuatan (streghts) & & & \\
\hline a. & Pencampuran pakan sendiri & 0,111 & 3,200 & 0.355 \\
\hline b. & telur yang dihasilkan standar pasar & 0,128 & 2,667 & 0,341 \\
\hline c. & Hubungan (kerjasama pemasaran) & 0.078 & 2,400 & 0,187 \\
\hline d. & mudah dalam mendapatkan modal & 0,111 & 2,400 & 0,266 \\
\hline \multirow[t]{2}{*}{ e. } & Lokasi budidaya yang strategis & 0,117 & 2,933 & 0,343 \\
\hline & & 0,545 & 13,610 & 1,492 \\
\hline 2 & kelemaha (weaknesses) & & & \\
\hline \multirow{2}{*}{ a. } & belum memenuhi permintaan pasar & 0,117 & 3,000 & 0,351 \\
\hline & Kurangnya sistem pencatatan laporan & 0,094 & 2,933 & 0,275 \\
\hline C. & Sifat telur perishable (mudah rusak) & 0,122 & 3,000 & 0,366 \\
\hline d. & $\begin{array}{l}\text { Peternaka seringkali dihadapkan pada } \\
\text { input produksi yang tinggi }\end{array}$ & 0,061 & 3.133 & 0,191 \\
\hline \multirow[t]{2}{*}{ e. } & Ketidakpastian informasi harga telur & 0,061 & 3,066 & 0,187 \\
\hline & Sub Total & 0,455 & 15,132 & 1,370 \\
\hline \multicolumn{2}{|c|}{ Total } & 1,000 & 28,742 & 2,862 \\
\hline
\end{tabular}

Faktor kekuatan dan kelemahan yang tercantum pada tabel 1 . dengan nilai berdasarkan pengaruh strategis terhadap peternakan ayam ras petelur. Berdasarkan Analisis Internal Strategic Factor Analysis Summary (IFAS) diketahui bahwa variabel yang dianalisa dijelaskan pada identifikasi factor kekuatan dan kelemahan di bawahini :

\section{Identifikasi Fakor-Faktor Kekuatan (Streghts)}

1. Pencampuran pakan sendiri menguranggi biaya pemeliharaan. Pakan merupakan output terbesar 
dalam manajemen pemeliharaan ayam ras petelur yaitu sekitar $60 \%$ dari manajemen pemeliharaan. Maka dari itu pembuatan pakan sendiri dengan mencapurankan jagung, katul, dan kosentrat dapat mengguranggi biaya.

2. kualitas telur yang dihasilkan sesuai dengan standar pasar.

3. Kualitas telur yang baik ditenukan dari bebeapa karakteristik seperti :

1. Kulittelur yang bersih

2. Cangkang telur yang tidak retak

3. Warna kulit telur yang berwarna cokat lebih baik di bandingkan dengan kulit telur yang bewana putih karena keteballan kulit telur yang berwarna coklat rata-rata $0,51 \mathrm{~mm}$, sedangkan ketebalan kulit telur yang berwarna putih ratarata $0,44 \mathrm{~mm}$.

4. Kerjasama antar pengepul terhadap kesepakatan harga telur yang setiap hari berubah-ubah.

5. Peternak mudah dalam mendapatka modal dari lembaga keuangan. Upaya mengembangkan usaha ayam ras petelur dengan menggunakan fasilitas kredit pada lembaga keuangan setempat. Selama ini kerjasama dengan pihak bank sangat baik, hal ini terlihat dari kepercayaan yang tinggi terhadap pihak peternak.

4. Lokasi budidaya yang staregis seperti jauh dari pemukiman penduduk, suhu dan kelembaban yang ideal yatu $\left(28,63^{\circ} \mathrm{C}\right.$ dan $\left.55-70 \%\right)$.

\section{Identifikasi fakor-faktor (weaknesses).}

Produksi telur ayam yang belum dapat memenuhi kebutuhan pasar menjadi salah satu kelemahan. Selain itu kurangnya system pencatatan laporan dapat menyulitkan dalam menganalisis usaha tani secara keseluruhan. Berbagai macam kelemahan yang muncul dalam peternakan ayam ras petelur dapat menjadian ancaman Oleh karena itu, dilakukan analisis strategi yang tepat untuk menghadapi permasalahan tersebut.

Tabel 2.Penentuan external strategic factor analysis summary (EFAS) terhadap peternakan ayam ras petelur.

\begin{tabular}{|c|c|c|c|c|}
\hline NO & FaktorStrategi External & \multirow[t]{2}{*}{ BOBOT } & \multirow[t]{2}{*}{ RATING } & \multirow[t]{2}{*}{ SKOR } \\
\hline 1 & peluang (opportunities) & & & \\
\hline a. & $\begin{array}{l}\text { Permintaan pasar akan telur ayam ras } \\
\text { cukup tinggi }\end{array}$ & 0,124 & 3,130 & 0,388 \\
\hline b. & $\begin{array}{l}\text { Kemudahan komunikasi dalam } \\
\text { memasarkan telur }\end{array}$ & 0,108 & 2,600 & 0,281 \\
\hline c. & $\begin{array}{l}\text { Sector perunggasan tetap bertahan } \\
\text { dalam keadaan krisis }\end{array}$ & 0,080 & 1,866 & 0,149 \\
\hline d. & telur sudah banyak dikenal & 0,090 & 3,266 & 0,294 \\
\hline \multirow[t]{2}{*}{ e. } & Faktor kebudayaan & 0,090 & 2,800 & 0,252 \\
\hline & & 0,492 & 13.66 & 1,364 \\
\hline 2 & Ancaman (Threats) & & & \\
\hline a. & Fluktuasi harga pakan & 0,073 & 2,933 & 0,214 \\
\hline b. & Fluktuasi harga telur & 0,119 & 3,000 & 0,357 \\
\hline c. & $\begin{array}{l}\text { Ancaman perdagangan bebas yang } \\
\text { tidak diberlakukan hambatan tarif } \\
\text { untuk biaya masuk produk luar negeri }\end{array}$ & 0,113 & 2,866 & 0,323 \\
\hline d. & $\begin{array}{l}\text { Pengaruh penukaran nilai rupiah } \\
\text { terhadap dolar }\end{array}$ & 0,113 & 3,200 & 0,361 \\
\hline \multirow[t]{3}{*}{ e. } & Penyebaranwabahpenyakit & 0,090 & 3,000 & 0,270 \\
\hline & Sub Total & 0.508 & 14,999 & 1,525 \\
\hline & Total & 1.000 & 28,659 & 2,889 \\
\hline
\end{tabular}

Tabel 3. Analisis rumusan strategi SWOT berdasarkan IFAS dan EFAS 


\begin{tabular}{|c|c|c|}
\hline EFAS & $\begin{array}{l}\text { STRENGHTS (S) } \\
\text { 1. Pencampuran pakan } \\
\text { sendiri yang dihasilkan } \\
\text { 2. Telur yang } \\
\text { standar pasar } \\
\text { 3. Hubungan (kerjasama } \\
\text { pemasaran) } \\
\text { 4. Mudah dalam } \\
\text { mendapatkan modal } \\
\text { 5. Lokasi budidaya yang } \\
\text { strategis }\end{array}$ & $\begin{array}{l}\text { WEAKNESSES (W) } \\
\text { 1. Belum memenuhi } \\
\text { permintaan pasar } \\
\text { 2. Kurangnya } \\
\text { pencatatan laporan } \\
\text { 3. Sifat telur sifatnya } \\
\text { perishable (mudah rusak) } \\
\text { 4. Peternakan seringkali } \\
\text { dihadapkan pada input } \\
\text { produksi yang tinggi } \\
\text { 5. Ketidakpastian informasi } \\
\text { harga telur }\end{array}$ \\
\hline $\begin{array}{l}\text { OPPORTUNITIES(O) } \\
\text { 1. Permintaan pasar } \\
\text { akan telur ayam } \\
\text { ras cukup tinggi } \\
\text { 2. Kemudahan } \\
\text { komunikasi dalam } \\
\text { memasarkan telur } \\
\text { 3. Sector } \\
\text { perunggasan } \\
\text { merupakan } \\
\text { bertahan dalam } \\
\text { keadaan krisis } \\
\text { Telur sudah } \\
\text { banyak dikenal } \\
\text { 5. Faktor } \\
\text { kebudayaan }\end{array}$ & $\begin{array}{l}\text { STRATEGI(SO) } \\
\text { 1. apabila kualitas atau } \\
\text { peroduksi yang di } \\
\text { hasilkan tetap stabil } \\
\text { maka yang dilakukan } \\
\text { adalah dengan } \\
\text { peningkatan kapasitas } \\
\text { produksi melalui } \\
\text { penambahan kandang } \\
\text { 2. Pendapatan modal } \\
\text { yang sangat cepat } \\
\text { dapat meningkatkan } \\
\text { populasi menjadi lebih } \\
\text { besar }\end{array}$ & $\begin{array}{l}\text { STRATEGI(WO) } \\
\text { 1. Pencatatan laporan dan } \\
\text { keuangan yang rinci dapat } \\
\text { membantu peternak dalam } \\
\text { situasi yang krisis. } \\
\text { 2. Memanfaatkan teknologi } \\
\text { secara maksimal. }\end{array}$ \\
\hline $\begin{array}{l}\text { THREATS (T) } \\
\begin{array}{l}\text { 1. Fluktuatif Harga } \\
\text { Pakan } \\
\text { 2. Fluktuasi Harga } \\
\text { Telur } \\
\text { 3. Ancaman } \\
\text { Perdagang'an } \\
\text { Bebas Yang Tidak } \\
\text { Diberlakukan Tarif } \\
\text { Untuk Biaya } \\
\text { Masuk Produk } \\
\text { Luar Negeri } \\
\text { 4. Pengaruh } \\
\text { penukaran nilai } \\
\text { rupiah terhadap } \\
\text { dolar } \\
\text { 5. Penyebaran } \\
\text { wabah penyakit }\end{array}\end{array}$ & $\begin{array}{l}\text { STRATEGI(ST) } \\
\text { 1. Peningkatan/ menjaga } \\
\text { peroduksi tetap setabil } \\
\text { dengan melalui } \\
\text { pengendalian dan } \\
\text { pengawasan terhadap } \\
\text { hama atau penyakit } \\
\text { ternak } \\
\text { 2. Melakukan diversifikasi } \\
\text { (penganekaragaman) }\end{array}$ & $\begin{array}{l}\text { STRATEGI(WT) } \\
\text { 1. Meminimalkan pengeluaran } \\
\text { untuk meningkatkan } \\
\text { pengembangan agribisnis } \\
\text { ayam ras petelur }\end{array}$ \\
\hline
\end{tabular}

$\begin{array}{cl}\text { variabel yang diamati pada } & \text { factor analysis summary (EFAS) adalah } \\ \text { tahapan penentuan external strategic } & \text { variabel peluang dan ancaman yang dapat }\end{array}$ 
berasal dari lingkungan ekternal maupun internal perusahaan. Kebutuhan pasar terhadap telur yang semakin meningkat, disertai dengan lokasi yang strategis menjadikan sebuah peluang untuk mengembangkan usaha peternakan ayam ras petelur khusunyadiwilayahKabupaten Kediri.

Sedangkan ancaman yang sampai saat ini masih dikhawatirkan oleh sebagian besar peternak ayam ras petelur adalah fluktuasi harga pada telur. Harga telur berfluktuasi sesuai dengan kondisi

\section{PEMBAHASAN}

Berikut ini merupakan tabel analisis nilai IFAS danEFAS :

\begin{tabular}{|c|c|c|}
\hline EFAS IFAS & S & $\mathbf{W}$ \\
\hline 0 & $\begin{array}{l}\text { SO } \\
\text { Menggunakan kekuatan internal untuk } \\
\text { memanfaatkan peluang eksternal } \\
\text { sebesar- besarnya } \\
=1,492+1,364 \\
=2,856\end{array}$ & $\begin{array}{l}\text { WO } \\
\text { Meminimalkan kelemahan } \\
\text { internal untuk memanfaatkan } \\
\text { peluang eksternal } \\
=1,370+1,364 \\
=2,734\end{array}$ \\
\hline $\mathbf{T}$ & $\begin{array}{l}\text { ST } \\
\text { Menggunakan kekuatan internal untuk } \\
\text { mengatasi ancaman eksternal secara } \\
\text { intensif } \\
=1,492+1,525 \\
=3,017\end{array}$ & $\begin{array}{l}\text { WT } \\
\text { Meminimalkan kelemahan } \\
\text { internal untuk menghindari } \\
\text { ancaman eksternal. } \\
=1,370+1,525 \\
=2,895\end{array}$ \\
\hline
\end{tabular}

Dari tabel di atas dapat di analisa bahwa internal strategic factor analysis summary (IFAS), factor kekuatan memiliki nilai sebesar 1,492 dan kelemahan dengan nilai 1,370 . Sedangkan padatabel external strategic factor analysis summary (EFAS) terlihat factor peluang dengan nilai 1,364 sedangkan factor ancaman sebesar 1,056 berdasarkan faktor yang mempengaruhi setrategi pengembangan ayam ras petelur di Kabupaten Kediri.

Faktor kekuatan diketahui memiliki nilai yang lebih besar dibandingkan Kelemahan dan factor peluang dalam pengembanggan ayam ras petelur lebih sedikit nilainya dibandingkan ancaman pengembanggan ayam ras. Hal yang harus di lakukan untuk pengembanggan ayam ras petelur adalah pembuatan strategi baru untuk pengembanggan usaha peternakan ayam ras petelur. pasar, banyak dipengaruhi oleh permintaan dan penawaran. Banyak faktor penyebab terjadinya fluktuasi harga diantaranya adalah sifat penawaran yang selalu berubah, produksi yang tidak dapat dihentikan sewaktu-waktu, serta permintaan yang bersifat musiman.

Disamping itu ancaman yang saat ini terjadi adalah menurunnya nilai tukar rupiah terhadap dolar yang sampai saat ini tidak dapat dihindari. 
dilakukan adalah dengan peningkatan kapasitas produksi ayam.

4. Pendapatan modal yang sangat cepat dapat meningkatkan populasi menjadi lebih besar.

\section{DAFTAR PUSTAKA}

Abidin, Z. 2003. Meningkatkan Produktivitas Ayam Ras Petelur. Agromedia Pustaka. Jakarta.

Achmanu dan Muharlien. 2011. IImu Ternak Unggas. UB Press. Malang.

Anonim. 2000. Budidaya ayam petelur (Gallus sp.). Kantor Deputi Menegristek Bidang

Pendayagunaan dan

Pemasyarakatan IImu

Pengetahuan. Jakarta.

Badan Pusat Statistik Provinsi Jawa Timur, 2016, Badan Pusat Statistik. Jakarta.

David FR. 2004. Manajemen Strategis :Konsep, Edisiketujuh. Sindoro A, penerjemah. Jakarta (ID): PT INDEKS.

David FR. 2009. Manajemen Strategis. Edisike - 12. Sunardi D, penerjemah. Jakarta (ID): Salemba Empat.

David, Fred. R. 2004. Manajemen Strategis. Edisi Kesembilan. PT. Intan Sejati Klaten. Jakarta.

Direktorat Jenderal Peternakan dan Kesehatan Hewan. 2012. Statistik Peternakan dan Kesehatan Hewan. Jakarta (ID): Direktorat Jenderal Peternakan dan Kesehatan Hewan.

Dublecz, K.,2011, poultry Nutrition: Lecture Notes for Students OF MSc courses Of Animal Science And Nurtition And Feed Safety, Unifersity Of Pannonia.

Efferin, Sujoko. Stevanus HD. Dan Yuliawati Tan. 2004. Metode
Penelitian Untuk Akuntansi. Bayu Media Publishing. Malang

Fadillah, R. 2004. ayam petelur komersial. PT. Agromedia pustaka. Jakarta.

Fajar Trisna Kurniawan. 2013. Strategi Pengembangan Agribisnis Peternakan Ayam Petelur di Kabupaten Tabanan: Jurnal Manajemen Agribisnis. Vol. 1, No. 2,53-66

Fitri, M. 2006. Strategi Pengembangan Usaha Sayuran Organik Pada Kelompok Tani "UsahataniBersama" Kabupaten Tanah Datar Sumatera Barat. Skripsi. Program Studi Manajemen Agribisnis. Fakultas Pertanian. InstitutPertanian Bogor. Bogor

Leeson, S., 2016, Introduction to Poultry Nutrition, Department of Animal and Poultry Science, University of Guelph in Ministry Of Agriculture Annual Publication, Food And Rural Affairs, Ontario, Canada.

Leonardo,H Dan Aritonang, 2012, Pengembangan Sistem Agribisnis Dalam Rangka Pembangunan Pertanian Berkelanjutan, Program Studi Agribisnis Fakultas Pertanian Universitas HKBP Nommensen Medan.

Lestari, P, I. 2009. Kajian Supply Chain Management: Analisis Relationship Marketing Antara Peternakan Pamulihan Farm Dengan Pemasok Dan Pelanggannya. Institut Pertanian Bogor.

Lolong, J. L. 2003. Proyeksi Penyerapan TenagaKerja Di Provinsi Sulawesi Utara.SkripsiFakultas Pertanian Universitas Sam Ratulangi, Manado.

Pabundu, Tika M. 2006. Metodologi Riset Bisnis. PT. Bumi Aksara. Jakarta.

PT Trouw Nutrition Indonesia. 2012, Eggducation. Jl. Selayar Blok A 3-2 | Cikarang Barat | Bekas. 
Pusat penelitian dan pengembanggan petenakan. 2017. Kebijakan pengendalian antibiotic growth promoters dan ractopamine dalam mendukung keamanan pangan nasional di http:/ /peternakan. litbang. pertanian.go.id/ index.php/ publikasi/ booklet/48627- (di akses 9 setember).

Rangkuti, Freddy.2001. Analisis SWOT Teknik Membedah Kasus Bisnis. Gramedia Pustaka Utama. Jakarta.

Rangkuti, freddy. 2004.Analisa SWOT Teknik Membedah Kasus Bisnis. Gramedia Pustaka Utama. Jakarta.

Rangkuti, freddy. 2008. Analisis SWOT Teknik Membedakan Kasus Bisnis. Jakarta : Gramedia Pusaka Utama.

Sianturi, Sri. R.2008. Analisis Strategi Pengembangan Usaha Esther Seafood. Program Studi Manajemen Agribisnis. Fakultas pertanian. IPB. Bogor

Sugiyono. 2013. Metode Penelitian Pendidikan. Alfabeta. Bandung.

Supriyono, R.A. 1998. ManajemenStrategi Dan KebijakanBisnis, EdisiKedua. BPFE.Yogyakarta.

SuratnodanLinkolin, A. 2008. Metodologi Penelitian Untuk Ekonomi dan Bisnis. Edisi 1.Cetakan 5. UPPSTIM YKPN. Yogyakarta.

Susilorini, E. 2011. Budi Daya 22 Ternak Potensial, Penerbit Swadaya. Jakarta
Undang - undang Republik Indonesia Nomor 36 Tahun 2009 tentang Kesehatan. Pasal 1.

W. Nuryadi. 2013. Perkembanggan manajemen strategi dalam perspektif teoristik dan analisi sempiris. Jornal akutansi Volll, No. 2, februari 2013, hal 115.

Yuanta, T. 2004. Dasarternak unggas. Penerbit kanisius.Yogyakarta.

Yunus, moch. 2016. Strategi dan kajian strategi. Surabaya. Universitas Airlangga.

Anynomous. 2012. Management Peternakan Ayam. http://www. Glory - farm. com. Diakses tanggal 10 September 2018.

Nurcholis, dkk 2009. Tatalaksana Pemeliharaan Ayam Ras Petelur Periode Layer Di Populer Farm Desa Kuncen Kecamatan Mijen Kota Semarang Vol 5. No 2, 2009, Mediagro

Nurhayati, Siti. 2008. Pendekatan QSPM sebaga Dasar Perumusan StrateginPeningkatan Pendapatan Asli Daerah Kabupaten Batang, Jawa Tengah. Jurnal Ekonomi Pembangunan Vol. 9 No. 1 Juni 2008, hal $72-82$. 